\title{
ANIMISTLIK KÕNELEMINE PUUDEGA KAHE LÄÄNEMERESOOME NÄITE PÕHJAL
}

\author{
Madis Arukask \\ Tartu Ülikool
}

\begin{abstract}
Ülevaade. See artikkel käsitleb puudega suhtlemist vadja ja vepsa rahvakultuuris. Vaatluse all on kaks juhtu, kus metsas marju-seeni korjav inimene on toonud puule (kuusk; kask) toiduandi ning puud kõnetades palunud temalt head korjesaaki või tervist. Vadja informant on ka metsas mälestanud teadmata surnuid. Lisaks personaalse suhtluspartneri või vahendaja rollile võib puud vaadelda ka laiemas usundilises (kosmogoonilises) ja kombestikulises kontekstis. Need juhud pakuvad huvi kui animistliku maailmavaate kajastused läänemeresoome rahvastel. Ühtlasi kutsuvad nad üles arutlema laiemalt läänemeresoomeliku ontoloogia üle, milles šamanistlik kultuuritüüp hakkas hiljemalt rauaajal asenduma teadjakesksega.
\end{abstract}

Märksõnad: animism, läänemeresoome rahvausk, puudega suhtlemine, teadja, vadja, vepsa

DOI: https://doi.org/10.12697/jeful.2017.8.1.02

\section{Sissejuhatus}

Venemaa loodeosa väikesearvulised läänemeresoome rahvad on olnud piirkonna põlisasukateks ammu enne 8. sajandist alanud idaslaavi invasiooni. Kunagisest ilmsesti hajusast ühtsusest põhjaalade metsavööndis on nüüdseks alles jäänud saareline asustuspilt, mille on kaasa toonud sajandite jooksul toimunud keeleline assimileerumine ja kokkusulamine põhjavenelastega. Läänemeresoome keeltes kõneleda oskavaid kakskeelseid inimesi (karjalaste rühmad, vepslased, Ingerimaa soomlased, isurid ja vadjalased, kelle igapäevases keelekasutuses on üleminek vene keelele või selle prevaleerimine tavalised) leidub tänapäeval Leningradi ja Vologda oblastis ning Karjala vabariigis paarikümne tuhande ringis ning nende arv väheneb järjest. Iseäranis kaks viimati mainitud rahvast Leningradi oblasti lääneosas on praeguseks juba peaaegu minetanud oma keelelis-kultuurilise eripära, olles igapäevaelus üle läinud vene keelele ja elulaadile. Karjalaste ja vepslaste 
asuala on olnud geograafiliselt enam perifeerne ning ilmsesti on ennekõike see taganud ka nende arvukama säilimise.

Olen teinud folkloristlikke välitöid vadja külades aastatel 19972003 ning vepslaste juures alates 2004. aastast tänaseni. Põhiliselt on mind huvitanud rahvausuga seotud folkloorižanrid: isiklikud kogemuslood, memoraadid, muistendid, loitsud ja itkud. Sellele lisaks olen talletanud usundilisi praktikaid: kommunikatsiooni teispoolsusega itkemisel, ravitsemist sõnamaagia abil, metsaga seotud käitumisviise ja rituaale. Eelistan oma informantidega suhelda võimalikult palju nende oma (s.o vepsa, varem ka vadja) keeles, minnes vaid vajadusel üle vene keelele. Mind huvitavat ainest kannavad oma keeles kõige paremini edasi vanema põlvkonna esindajad, kelle lapsepõlv jääb osaliselt sõjaeelsesse perioodi. Samas ei kadunud rahvapärase õigeusuga segunenud animistlik maailmapilt ka pärast teist maailmasõda. Nõukogulik ateismipropaganda ei suutnud silmatorkavalt lammutada traditsioonilist maailmapilti, mida iseäranis vanem generatsioon kannab ka tänapäeval.

Läänemeresoome rahvastele iseloomulik kultuuritüüp hakkas välja kujunema pronksiajal, kui läänepoolsemad soome-ugri hõimud sattusid kestvamasse kontakti indogermaani põlluharijarahvastega (vrd Carpelan 2006, Kallio 2015, Lang 2016 jt). See pani aluse šamanistliku, pigem küttimisele ja korilusele keskendunud kultuuritüübi ning maaviljeluse sümbioosile, millest rauaajal arenes välja iseloomulik teadjakeskne kultuuritüüp (Siikala 2002, Frog 2013). Teadja praktikad erinesid oluliselt šamanistlikest. Iseloomulik joon on siin transi ja šamaanilaulude asendumine loitsude kasutamisega, mis ei eeldanud sedavõrd intensiivset ja kurnavat "ärakäimist" muutunud teadvuse seisundis. Teadja suhted oma abivaimudega on olnud domineerivamad ning teadja rollikäitumine pigem sooneutraalse või ka transseksuaalse šamaani omast märksa maskuliinsem. Selles võib näha germaani sõdalaskultuuri mõjusid läänemeresoomlastele (vrd Siikala 2002: 335 jj).

Väga tõenäoliselt esinesid läänemeresoomlastel šamanistlik ja teadjakultuur veel pikalt kõrvuti, millest annavad tunnistust iseloomulikud näited karjala folkloorist (Siikala 2002: 264-280) ning mõisteline vahetegemine kaht sorti usundispetsialistil: noita/noid/nõid (kui pigem šamanistlik või isegi negatiivne roll) vs. tietäjä/tedai/teadja (vrd ka Frog 2013: 59, 67-68). Ootuspäraselt pole meie päeviks läänemeresoomlastel šamanistlikku kultuuri säilinud, küll aga võib nt vepslaste hulgas (nagu Põhja-Venemaal üldiselt) nüüdki kohata ravitsejaid / ennustajaid / kadunute otsijaid, kes mahuvad tavapärase teadja rolli sisse. 


\section{Metsa roll läänemeresoomelikus kultuuritüübis}

Elatusalaliselt on Venemaa läänemeresoomlastele - kui rannikul elavad merekalastuse ja meresõiduga tegelenud isurid ja vadjalased kõrvale jätta - sajandite vältel iseloomulik olnud tegelemine küttimise, koriluse, metsakarjatamise ja alepõllundusega. Traditsiooniökoloogiliselt (vrd Honko 1994: 68) on see tähendanud põlispõllundusega tegelejatest hoopis teistsugust loodussuhet, mis usundiliselt on väljendunud dialoogilises partnersuhtes animistlike vaimolenditega. Eriti vepslaste puhul torkab silma selliste suhtluspraktikate suhteline rohkus, seda ka tänapäeval. Metsas või võõras kohas üldse tervitatakse kohavaime kindlate vormelite või ka vabalt sõnastatud pöördumistega. Seega on meil Dell Hymesi mõtet kasutades tegemist "kogukonna enda teooriaga keelekasutusest ja vastavatest suhtluspraktikatest". Hymesi tsiteerides võime tõdeda, et (...) kogukonnad erinevad üksteisest märgatavalt kõnelemisviiside (ways of speaking), repertuaari- ja suhtlusmustrite ning kõne rolli ja tähenduse poolest. See viitab erinevustele uskumustes, väärtustes, võrdlusrühmades, normides jms, mis eksisteerivad keelekasutussüsteemis ja selle omandamises laste poolt (Hymes 1989: 33).

Tänapäevalgi ei kategoriseeru selline animistlik temaatika vepslastel alati otseselt üleloomuliku või fiktiivse alla, vaid seda võetakse igapäevaelu loomuliku osana ja vastavat suhtlemist normaalse käitumiskoodina. Niisamuti ei kahelda nt ka metsavaimu olemasolus, tema kohalolekus siis, kui inimene viibib metsas, mis pole talle siiski mitte otseselt kodune domeen. Kuigi ollakse elanud üle 1000 aasta (vähemalt formaalselt) kristlikus kultuuriruumis, pole paljud sellele eelnenud tõekspidamised ja praktikad muutunud.

Sellegipoolest pole eespool kirjeldatu puhul tegemist mingite avalike või kollektiivsete rituaalidega, vaid personaalse kultuuriliselt omandatud koodiga. Vepslastega kõneldes võib saada juhendust, kuidas tuleb kohavaimude poole pöörduda. Tegu ei ole mingi salateaduse, vaid loomuliku ja viisipärase kombekusega, see võib olla traditsiooniline vormellik tekst, mida tuleb öelda metsa piirile jõudes või metsa sisenedes. Sarnaseid pöördumisi on varem üles kirjutatud ka muudelt läänemeresoome rahvastelt, näiteks on 57-aastane vadjalanna D. L. 1937. aastal rääkinud soome uurija Aili Laihole: Mie ommiil lapsil ain sanon, kui määt messää marjoi korjamaa, ain pittää tervehtää: "Terv, metšä, terve metšän haldialain, terv metšän emäntä!'” [Ma oma lastele ikka ütlen, kui lähed metsa marju korjama, ikka pead tervitama: "Tere, mets, tere, metsa haldjas, tere, metsa emand!'] (SKS). 
Välitöödel vepslaste juures olen näinud ka seda, kuidas metsas käies (nt seeni korjates) on puhkepeatuse järel jäetud metsaisandale puu alla söögipoolist paiga kasutamise eest.

Metsale ja/või seda esindavale metsavaimule/"metsarahvale" agentsuse omistamine on loomulikult universaalne nähtus, mida võib seletada inimolemusele omase joonena näha, luua või kujutada enda ümber (üleloomulikke) olendeid (Boyer 2002). Sellise, küllap evolutsioonilise käitumise tagamaad võivad olla sootsiumi liikmete ühiskondlikult normatiivse käitumise tagamises, vajaduses tagada (loomult omakasupüüdliku) inimkäitumise üle mingi üldisem kontroll, mis aitab kaasa sootsiumi ühisele toimetulekule ja selle liikmete konsolideerumisele. Uusanimistlikust vaatenurgast pole selline suhtevorm käsitletav primitiivse mõtlemisvea või lapsikusena, vaid selles väljendub respekt kõige keskkonnas olemasoleva suhtes (Harvey 2005: xi-xii). Samas pole animismi mõtet ülearu samastada nüüdisaegse loodusteadustepõhise ökoloogilise mõtteviisiga. Animismis võib pigem näha sarnase sisemise (inimliku) olemisvormi omistamist väliselt teistsugustele eluvormidele (loomadele, lindudele, puudele, taimedele jne; vrd Descola 2013: 121$122,129 \mathrm{jj}$ ), mis on üldlevinud ennekõike küttide ja korilaste juures üle maailma ning peamiselt väljaspool euroopalikku-modernset kultuuriruumi. Vadjalaste ja vepslaste puhul (nagu juba öeldud) peame tähele panema, et nende kontakt n-ö tsiviliseeritud maailmaga on väga pikaajaline (hiljemalt Rooma rauaajast kuni nõukoguliku moderniseerumiseni). Seda enam pakuvad huvi neil säilinud animistlikud jooned.

On tähelepanuväärne, et vepslastel ei ole toimunud metsa ulatuslikumat demoniseerumist, mida on võinud eri kirjalike andmete põhjal täheldada enamikul Põhja-Euroopa metsavööndi rahvastel vähemalt viimastel sajanditel. Õigeusk on ühtpidi küll integreerinud, sageli aga ka vastandanud animistlikku vaimude maailma kristlikule ning näiteid sellest võib leida ka läänemeresoome rahvastelt (nt Järvinen 2004). Metsa on mõne vadja teate põhjal (VE X: 7, Ariste 1970: 96) võidud pidada kuradi asupaigaks, Karjalas on kunagised looduslikud pühapaigad võinud omandada negatiivse konnotatsiooni jne. On tõenäoline, et metsakarjatamise ja alepõllunduse viljelemisel, kus kontakt metsa ja inimeste vahel on pikaajalisem, on peale jäänud siiski partnersuhe. Nii on see vepslaste puhul, kus alepõllundusega tegeldi paiguti veel ka pärast sõda nõukogude ühismajandites ning kus maagiapõhine kariloomade metsakarjatamine on paiguti kestnud veel meie päevini. Viimases tegevuses on taas tähtis osa olnud kogukonna teadjatel ja metsavaimuga maagilise lepingu (vene obhod, vepsa ümbarduz) sõlminud karjustel (vt Arukask 2016). Siiski on ka vepslaste traditsiooniline maailmapilt tänapäeval 
vähehaaval fragmenteerumas maal elavate kogukondade vähenemise, massimeedia pealetungi ja üldise venestumise mõjul.

Selles artiklis vaadeldakse lähemalt kaht üksikjuhtu, milles inimene suhtleb metsas puudega. Neis ei toimu otsest rituaalset pöördumist metsavaimu poole, vaid tegemist on personaalsete, ilmselt traditsioonilise mustri põhjal kujunenud isiklike rituaalidega, kus puu esineb vestluspartneri ja/või vahendajana siin- ja teispoolsuse vahel. Need juhud ei kategoriseeru "tavapäraste" rituaalidena looduslikes pühapaikades (kuigi mingit sarnasust võib täheldada). Vadjalastelt on küll saadud teateid looduslikest pühapaikadest ning neis läbi viidud rituaalidest (vt nt Västrik 2007: 67-69, 134-136, Kon'kova 2009: 138-139), viiteid sellele leidub ka vepslastelt (vt nt Pal'vadre 2015: 198). Kirjeldan selles artiklis ühe eelmisel sajandil elanud vadja naise rituaale professor Paul Ariste 1970-ndate keskel tehtud üleskirjutuste põhjal ning oma aastatel 2010-2015 tehtud välitöödel kohatud vepsa naise rituaale metsas.

\section{Kaks vaadeldavat juhtu}

Tartu Ülikooli soome-ugri keelte professor Paul Ariste (1905-1990) oli kahtlemata oma aja juhtivaid fennougriste. Kümnete keelte seas, mida ta valdas, oli tema lemmikuks just vadja keel. Esimese ekspeditsiooni vadjalaste juurde tegi Ariste aastal 1942, teise maailmasõja ajal, mil Eesti teadlastel õnnestus rinde itta liikumise tõttu arendada uurimistegevust ka Nõukogude Liidu territooriumil. Ariste regulaarsemad välitööd vadjalaste juures said alguse siiski 1960. aastatel ning kestsid kuni 1980-ndate alguseni. Lisaks keelenäidete talletamisele jagus Aristel silmatorkavalt huvi ka inimeste traditsioonilise eluviisi ja folkloori vastu. Suure osa tema käsikirjalistest vadja materjalidest moodustavadki inimeste kõneldud jutud ja teated oma uskumustest ning praktikatest. Samas polnud Ariste otseselt usundiuurija, folklorist või antropoloog, seetõttu võib arvata, et sihipärasem erialasem süüvimine ühte või teise teemasse oleks andnud veelgi rikkalikuma ja tihedama materjalikorpuse, seda ka meid siin huvitaval teemal.

Eesti Kirjandusmuuseumi Eesti rahvaluule arhiivis on 23 mapitäit foneetilises transkriptsioonis materjale, pealkirjastatud "Vadja etnoloogia" (VE). Neis figureerib kümmekond võtmeinformanti, valdavalt 19. sajandi lõpul sündinud inimest, keda Ariste aastate jooksul korduvalt külastas ning kellega tal olid välja kujunenud sõbralikud ja lähedased suhted. Paljude muude teemade seas tuleb ette teavet inimeste suhtlemisest puude ning (mets)loomadega. Üks Ariste armastatumaid 
informante, 1891. aastal sündinud vadja rahvalaulik ja ravitseja O. F. tavatses kodustada harakaid ja vareseid ning omaaegsetel fotodel võibki teda sageli näha, linnud õlgadel või ta läheduses istumas. Ta on Aristele rääkinud, kuidas kohtus metsasihil põdraga, kellega ta pikalt kõneles oma elust, samuti sellest, kuidas ta metsas lastud karult sai iselaadse manipulatsiooni abil - karu keha jäsemeid pidi diagonaalselt sõrmevaksaga "mõõtes" - lisa oma ravijavõimetele.

Mõnel korral on ta Aristele rääkinud ka oma personaalsetest rituaalidest ühe teatud kuusepuuga, kui käib metsas seenel või marjul. Olgu siin toodud mõned selleteemalised intervjuukohad 1974. aastast (säilitatud on algupärane üleskirjutusviis foneetilises transkriptsioonis):

ku mēn meccäa obakkāa, siz vetan kās. pān kormunā, konfettia, libo pečeńńä.

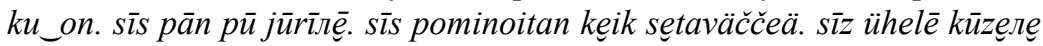

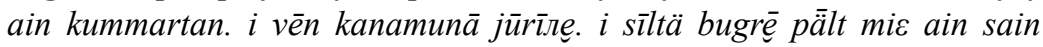

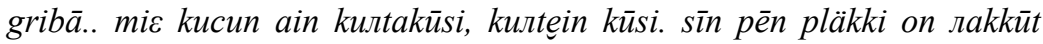

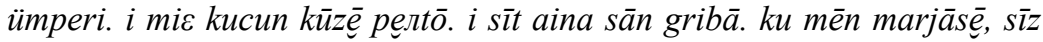
marjamättäle tōž mitälē vēn, siputan. sìz linnud nokitāa.

[Kui lähen metsa seenele, siis võtan kaasa. Panen tasku komme või küpsiseid. Kui on. Siis panen puu juurtele. Siis mälestan kõiki sõjamehi. Siis ühele kuusele aina kummardan. Ja panen kanamuna juurtele. Ja sealt künka pealt ma aina sain seeni. Ma kutsun mundkui "kuldakuusi", kuldne kuusk. Siin väike ala on lage ümberringi. Ja mina kutsun (seda) kuusepõlluks. Ja siit aina saan seeni. Kui lähen marjule, siis marjamättale taas midagi panen, puistan. Siis linnud nokivad.] (VE XVII: 130-131)

Ning teisel korral samal aastal:

ja // sìz on ügs kūs // sitä kucunči // kuлtaine kūsi // senē jалал / jẹka kerta //vēn / kẹns konfetā // kenss buлkā // kẹnz mitäči // kaivon avvā ja / sìs pān // sìz vēn kana munā // jūriлa // i pominoitan kẹik // nē / setaväččèä // čen on

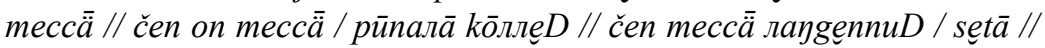

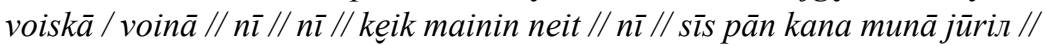

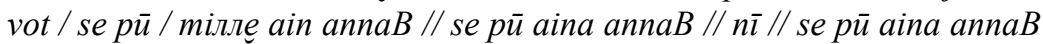
// kuлtaine kūsi // (...) sūt annan i / kęik // selle kūzęл //

[Ja siis on üks kuusk. Seda kutsungi kuldne kuusk, selle tüvele iga kord toon kord kommi, kord saia, kord midagi muud, kaevan augu ja siis panen, siis toon kanamuna juurtele ja mälestan kõiki neid sõjamehi, kes on metsa, kes on metsa puu alla surnud, kes on metsa langenud, sõjaväge, nii, nii. Kõiki nimetan neid. Nii siis panen kanamuna juurtele, vot see puu mulle aina annab, see puu aina annab nii. See puu aina annab, kuldne kuusk (...) suud annan ja kõike sellele kuusele.] (VE XVIII: 123) 
Selle materjaliga esimest korda ligi 20 aastat tagasi kokku puutudes pidasin selliseid tekste pigem personaalse usundilise idiolekti näideteks, milles arvasin olevat tubli annuse modernsest maailmast pärit lüürilisust. Hiljem, olles vepslaste juures kokku puutunud elava rahvausuga, tuli mul oma seisukohta revideerima asuda. Lisaks rikkalikule vepsa metsa ja sealsete uskumusolenditega seotud materjalile (kohtumised metsavaimuga, temalt kadunud loomade ja inimeste kohta küsimine ja nende tagasinõudmine, eksimislood jne) tuli ette ka puudega suhtlemise teema. Alates 2010. aastast olen intervjueerinud 1932. aastal sündinud naisinformanti, kelle rikkalikus usundilises repertuaaris esineb seda teemat regulaarselt. Esitan siin ühe iseloomuliku intervjuukatke 2010. aastast:

ižändaižele... mänen, da tesharad nakka-no, tesharad nakka-no, tesharaddorogad mändasoi.. sižutamoi... mecižändaižed, mečemägaižed, pästkätei mindai metžaiheže töiä, ankatei mińoi marjoid, griboid, ankad mińei terhud, väged... no, mińa kaika ljud́an, kaika antasoi mińei, rissitud - kui sa ljusid griboid da śened? ljusin mińa ičein tahoil, lähtežkanden, mecas koiranke kaika mińei... koir... mikšed-ni suhrižed libo kandoižele, lindoižele da... likeidam, śüöndad... emägeižele da ižändaižele... mecaspäi lähton, mesta tulon, sille tahole, mesta, kumardamoi: spasibo ižändäižed, emägaižed, andoite minei terhuh, andoite väged, andoite marjoid, griboid. Spasibo, kalliš sinä minun armaz mecaine, kaika ńinga sanun. mecas kävelen, da surdun, koivud da sured, sištazoi, mägež-da mogo, miš krěšus libuda... koivužen sebädan - armaz sińä koivuine, lehed́ad sinun lehtoižed, tihedad sinun okžaižed, armaz mińun sińä, puhud, anda sińä minui terhud, anda väged, abuda tämbei minei kod́e sadhas. Noh, vei minei čoma, mecäs kävelen ka, mińa voin sile, en läžu, kodiž kaik aig läžuna, a mečäs, siga prijatno kävelda [(Mets)isandale (ütlen)... lähen, ja teeharud niimoodi, teeharud niimoodi, teeharud-rajad lähen, seisatan... metsaisandad, metsaemandad, lubage mind teie metsa, andke mulle marju, seeni, andke mulle tervist, jõudu... noh, mina kõike leian, kõike antakse mulle, inimesed (küsivad) - kuidas sa leidsid marju ja seeni? Leidsin mina oma kohtadest, hakkan minema, metsas, koeraga kõik minu... koer... mõned kuivikud (?) kas kändudele, lindudele ja... lõikan, söödan... emandale ja isandale... metsast tulen, (teatud) kohale tulen, sellele kohale kummardan: aitäh, isandad, emandad, andsite mulle tervist, andsite jõudu, andsite marju, seeni. aitäh, kallis sina minu armas metsake, kõik niimoodi ütlen. metsas käin, ja väsin, suured kased, peatun, selline mägi (?), et üles (?) ronida... kallistan kaske - sina armas kaseke, värsked (on) sinu lehed, tihedad su oksad, armas (oled) sa mulle, puuke, anna sina mulle tervist, anna jõudu, aita mul täna koju jõuda. Noh, (?) mind kenasti, metsas (kui) käin, (siis) seal ma suudan, ei põe, kodus kogu aeg põen, aga metsas, seal on hea käia.] 
Mõnevõrra katkendlikus suulises teates sisaldub informatsioon, mille kohaselt palub ja saab informant metsas marjul ja seenel käies teatud kasepuult (või kaskedelt üldse?) jõudu ja energiat. Nagu vadja tekstis kuusele, nii tuuakse siin metsa kaasa koduseid ande. Jõudu ja tervist palutakse ka metsavaimudelt ja/või metsalt üldse. Iseloomulik on, et kasepuu poole pöördutakse deminutiivselt - mis iseenesest pole vepsa keeles sugugi haruldane. Tundub, et idapoolsetel läänemeresoome rahvastel viitab see, et igapäevakõnes kasutatakse sageli deminutiive, mis (erinevalt nt vene keelest) pole grammatiseerunud, suhtluspraktikana üldse pidevale elukeskkonnaga suhete hoidmisele, ümbritseva personifitseerimisele.

2015. aasta suvel õnnestus mul M. A. suhtlemist kasepuuga ka näha ja filmida. M. A. ei käinud enam regulaarselt metsas marjul, seda ei lubanud tema vanus (üle 80 a) ega tervis. Tulles seekord siiski valitud kase juurde, pani ta kepi käest, võttis kahe käega seistes puu ümbert kinni ning aeg-ajalt tüve ülalt alla silitades lausus:

koivuińe, koivuińe, armas sińä minun puhud. olęd sinä kaznu sureks, tihedaks, armas mid̈ä vepsoide puhud. andai sińä mińei terhud, vägüd-sa. lehedad sinun lehtoišed-ne, tihedad sinun oksaišed-ne. kazva siñä sureks, čomaks-sa, midää armas puhud-se sińä. mi sind ei voi mi nähdä. andad mile terhud, andad mile väged, anda mile kebnjad dorogad, terhud sadas täna mi kod́he, armas koivuine, sińä, anda... vähen vilud teged mile.

[Kaseke, kaseke, armas sina, minu puuke. Oled sina kasvanud suureks, tihedaks, armas meie vepslaste puuke. Anna sina mulle tervist, jõudu. Pehmed on su lehekesed, tihedad on su oksakesed. Kasva sina suureks, ilusaks, mu armas puuke sina. Sind ei või ma näha (iga kord). Annad mulle tervist, annad mulle jõudu, anna mulle kerget (kodu)teed, tervist täna kojusaamiseks, armas kaseke, anna... natuke varju annad mulle.]

See kõnetus kestis umbes minuti, misjärel ta võttis kepi ja liikus puu juurest eemale. Siis otsustas ta aga laulda veel vana suvistepüha (õigeusklikus pruugis troitsa) aegse ringmängulaulu, mida noorusest mäletas ja mis oli pühendatud kasepuule. Tava kohaselt toodi troitsa-nädalal metsast väiksem kasepuu, mille ümber lauldi ja tantsiti. Puult murti oksi. Laul sisaldas samuti kase suureks ja tihedaks kasvamise motiive, sarnaseid, mida ta kasutas nüüdki puu kõnetamisel.

Veel kõneles ta sel korral, et pole juba kolm aastat hästi metsa saanud, aga värske metsaõhk annab tervist. Mets annab tervist ja kaseke annab tervist. Kask annab mahla, ja kui kevadel seda võtad ja jood, oled terve, ei hakka valutama ei rinnus, ei südames. Kui kütad ahju, anna- 
vad kasehalud head sooja ning kalitka'sid (kohalikult levinud küpsetis) küpsetades saavad need kasehalgudega pruunikaks. Sauna kasehalgudega küttes saab head leili. Ta rääkis, et enne tehti kasetohust märsse ja karjused tegid väikseid korve, ning seletas, kuidas kaselt tohtu võeti: murti oks ja sellest keerutati tüve mööda allapoole ringi kasetohu lint puu küljest. Lõpuks lisas ta veel kord, et kaseke on "meile vepslastele" selline armas puuke.

Et selline praktika kasepuudelt tervist ja jõudu paluda on vepslastel laiemalt levinud, kinnitavad ka muud uurimused (vrd Vinokurova 2015: 182). Samuti on ilmne kase tähtis osa metsarahvaste majanduselus nii hea küttepuuna kui ka tarbeasjade materjalina.

\section{$* * *$}

Vaadeldavates intervjuutekstides on kesksed teemad tervise ja jõu, samuti hea seene- või marjasaagi palumine; vadja tekstides ka teadmata kadunud surnute mälestamise temaatika. Võimalik, et oluline on siin puu liigilisus - kuuski või kuuseoksi kasutatakse matustel tõrjemaagilises kontekstis. Kuigi M. A. erinevalt O. F-ist metsas surnute mälestamisega ei tegele, on vepsa rahvakultuuris ka kasel seos surnute ilmaga: surnuitkudes kujutatakse kaske ja selle alumist oksa piirina siin- ja teispoolsuse vahel (Vinokurova 2015: 182). Kask on seega otsekui kahe ilma vahendaja. Kask maailmapuuna on soome-ugri rahvaste mütoloogilises maailmapildis laiemalt levinud (vrd Napolskikh 1992).

Teadmata kadunute mälestamine kindlate puude juures on iseäranis vadjalastel universaalsem joon. Vadja surnuaedadel (mis tegelikult kujutavad endast metsaaluseid piiratud alasid nagu metsavööndis üldse) on siiani tava mälestada selliseid kadunuid mõne kindla okaspuu juures. Puule on selle tarvis mõnikord kinnitatud ka linnumajakest meenutav ehitis, kuhu mälestaja saab tuua teri või mingit muud toidupoolist "jumala lindudele" kui vahendajatele kahe ilma vahel. Lindudele toodavat toidupoolist mainib aga ka vepsa informant M. A. Toidu ning ühiste kogukondlike haual söömiste osa surnute mälestamisel on õigeusklikus rahvakultuuris üldlevinud. Seda arhetüüpi on järginud ka $O$. F. oma armastatud kuuse juures, võttes kaasa kanamuna kui traditsioonilise mälestusroa ning kaevates mälestamiseks võetud toiduaineid kuuse juure juurde maa sisse.

Surnute kogukonna ja saagiviljakuse seotus on rahvausus vägagi levinud joon. Surm ja viljakus ning teispoolsusest selle (ja ka tervise) palumine on õigeusklikus rahvakultuuris universaalne. Seda võibjälgida seoses kevadsuviste viljakus- ning mälestamisrituaalidega, samuti väga 
otseselt nii läänemeresoome kui ka Põhja-Vene itkutekstides, kus hauas oleva surnuga suheldes palutakse temalt (ja lahkunute kogukonnalt) nii tervist kui ka üldist edenemist. Sellised mälestamisrituaalid pole kunagi personaalsed, vaid surnute ilma poole pöörduv inimene (nt itkeja) esineb jõudu ja edenemist paludes üldiselt kogu kogukonna nimel. Siin vaadeldavad informandid metsas itkemisega ei tegelnud, kuigi selline praktika pole iseenesest võimatu.

On tähelepanuväärne, et mõlemad informandid kõnelevad mingisugusest kindlast alast palutava puu läheduses, kust nad soovitud metsaande saavad. O. F. nimetab seda "kuusepõlluks". Ka M. A. saab marju ja seeni mingist kindlast "oma kohast". Mets ei ole seega homogeenne piirkond, vaid selles eristuvad kindlad eritähenduslikud paigad, mis on seotud rituaalide ja saagiga. Küttidel ja korilastel on metsa selline diferentseeritus suhteliselt ootuspärane.

Tähelepanu väärib veel M. A. pühendunud jutt kasest kui vepslastele olulisest puust, millelt saab lisaks tervise ja saagi palumisele paljut muudki, mis vajalik nii terviseks (mahla, saunaleili) kui ka igapäevaeluks (halge, tohtu). Juhuslik pole kase osa ka troitsa-rituaalis, kus seda võib vaadelda maailmapuuna (sarnaselt kogu muu soome-ugri või/ja Põhja-Vene kultuuriruumiga). Seega on kasel siin M. A. jaoks nii personaalne kui samas ka laiem (kosmogooniline) tähendus. Need tähendused näivad tema jaoks olevat võrdselt aktuaalsed.

\section{Puudega suhtlemise tagamaadest metsarahvastel}

Vaatlusalused juhud panevad küsima, mis on sellise puu roll ja positsioon läänemeresoome ontoloogias ja mida see kõneleb animismist nende rahvaste puhul.

Vaadeldud juhtudel on puudel ühtpidi selge personaalsus partnerina, kellega saab vestelda. Universaalsemas plaanis on nad aga vahendajad siin- ja sealpoolsuse vahel. Tahtmata öelda, et üks peaks siin teist välistama (s.t partner vs. vahendaja), püüaksin siin siiski neil kahel dimensioonil vahet teha. Animism maailmavaate ja elatava praktikana tähendab kõige ümbritseva elusust, seda mitte lihtsalt bioloogilises mõttes, vaid elususe, personaalsuse ja agentsuse omistamist nii fauna kui ka floora esindajatele, aga ka looduskooslustele, paikkondadele või mineraalide maailmale (jne). Loomulikult on kartesiaanlik õhtumaine suhtumine näinud selles "primitiivse" inimese mõtteliialdust või viga asjade "tegelikust" olemusest arusaamisel. Seevastu tänapäeva 
antropoloogias nähakse sellist käitumist ja mõttemaailma kui tõendit inimese ja rahvaste võimest suhelda keskkonnaga vastastikku austavalt ning võrdsetelt alustelt lähtuvalt. Selle (neo-)animistliku kontseptsiooni üks eestkõnelejaid Graham Harvey on taimedega suhtlemise kohta maininud järgmist:

Siiski, mõned animistid kõnelevad taimedega ja kuulavad taimi, milles võib näha nii austavat suhtlemist kui ka dialoogi info vahetamisel. Nad kinnitavad, et pundel või seentel on näiteks soov omal moel suhelda asjadest, mis oleksid muidu teadmata ja jääksidki tundmatuks (Harvey 2005: 104).

Sellisel üldisel personifitseerimisel võivad siiski olla oma kultuurilised, detailides huvipakkuvad erijuhud. Tuntuimaid näiteid sellest on ehk Eduardo Viveiros de Castro arendatud perspektivismi kontseptsioon, mida võib tähele panna mitme Ameerika põlisrahva (ja küllap mitte ainult nende) juures:

Tavaliselt, normaalsetes olukordades, näevad inimesed inimesi kui inimesi ja loomi kui loomi; nagu vaimude nägemine, kes on tavaliselt nähtamatud olendid, viitab kindlalt, et "olukord" ei ole normaalne. Loomad (kiskjad) ja vaimud näevad aga inimesi kui (saak)loomi samal moel, nagu (saak)loomad näevad inimesi nagu vaime või kiskjaid. Sarnaselt näevad loomad ja vaimud endid kui inimesi: nad võtavad endid kui antropomorfseid olendeid (või muntuvad neiks), kui nad on oma majades või külades, ja nad tajuvad oma käitumisviisi ja tunnuseid kultuurilises vormis: nad näevad oma toitu inimeste toiduna (jaaguarid näevad verd maniokimahlana, raisakotkad näevad usse mädanevas lihas nagu küpsetatud kala jne), nad näevad oma kehalisi tunnuseid (karvkatet, sulgi, kü̈̈si, nokki) kui kehakaunistusi või kultuurilisi tööriistu, nad näevad oma ühiskondlikku süsteemi korraldatuna samal moel inimühiskonna institutsioonidega (pealike, šamaanide, tseremooniate, eksogaamsete pooltega jne) (Viveiros de Castro 2012: 47-48).

Neoanimistliku "võrdse läbisaamise" printsiibi asemel võib see suhe põliskultuurides olla niisiis ka diferentseeritud. Inimlikke ja mitteinimlikke elusolendeid on eri liike ning nende vahel võib eksisteerida ka mingi hierarhiline või antagonistlik või muu suhe (mis ei välista samas hingestatust ja personifitseeritust kui sellist).

Õigeusklikus rahvakultuuris (ka vaadeldavatel läänemeresoome rahvastel) on selgelt eristatud elavate inimeste ja surnud esivanemate kategooria. Moodustades ühest küljest hõimkondlikul baasil ühtse kogukonna, eristuvad ja distantseeruvad surnud esivanemad aja jooksul elavatest. Kahe poole vahel hoitakse suhet üleval nt hiljuti lahkunud 
kadunukese kaudu, kelle haual itkedes edastab elavate kogukonna esindaja infot. Elavate jaoks on kalmus olija otsekui vahendaja, kellelt palutakse sõnumite edasiviimist surnud esivanemate kogukonnale ning sealtpoolt edenemise ja heasoovlikkuse küsimist.

Näib, et toodud läänemeresoome näidete puhul on puud sellesarnased vahendajad, kelle personifitseeritusel on laiem taust kui vaid isiklik "sõprussuhe". M. A. tekstis seguneb konkreetselt vahendajapuult küsitav-saadav jõud metsalt ja metsavaimudelt saadavaga - need otsekui samastuvad. O. F-i "kuldne kuusk" on küll suhtluspartner, samas aga ka vahelüli teadmata kadunute mälestamisel, sarnaselt vadja kalmistutel olevate mälestamispuudega.

Vaadeldes kaske kui rituaalipuud (troitsa kombestikus) või maailmapuud üldisemalt, on meie ees juba mõnevõrra abstraktsemal tasemel asuv persoon. Kevadsuvistes rituaalides on metsast toodud puudel ja okstel olnud samuti tervist ja edenemist andev vägi. Pühade lõpus on õigeusklikus rahvakultuuris roheluse/metsa sümboolikaga koos saadetud inimkogukonnast ära ka lõppeva aastaajaga (kevad) talletunud negatiivset energiat. Nii on ärasaadetavat negatiivset võinud kehastada ka jõkke heidetud troitsa-kask (vrd Judin 1999: 147-148).

Suhe mälestusrituaalide vahendajasse (hauas olevasse kadunukesse) on traditsioonilises kultuuris olnud selgelt ambivalentne. Mälestamispraktikad on ühtlasi olnud ka siin- ja sealpoolsuse vahelised turvamispraktikad, milles on taas ja taas markeeritud kahe ilma piiri, et seda elavate kontrolli all pidada (Arukask 2011: 137-140). Ülaltoodud tekstides ei näe me aga otsest ambivalentsust (kartust) suhtluspartneriks olevate puude suhtes. Mõlemal juhul näivad puud olevat ühemõtteliselt positiivsed, abi ja turvatunnet pakkuvad persoonid. On tähelepanuväärne, et olukorras, kus ka animistlikul metsavaimul (keda vepsa kogemuslugudes on samuti kujutatud puusarnasena - puukõrgusena - vrd Salve 1995: 418, 428) kui laialt levinud uskumusolendil võib õigeusklikus läänemeresoome rahvakultuuris olla negatiivseid deemonlikke jooni, siis kirjeldatud juhtude puhul kuusel või kasel sellist konnotatsiooni ei näi olevat. Tuleb järeldada, et puude palumine ja nendega suhtlemine kuulub selgemalt kristlike uskumuste ja ideoloogiate eelsesse traditsioonikihti.

M. A. suhe kasepuusse on samas väga praktiline. Sedasama olulist puuliiki saab materiaalselt ära kasutada: koorida, raiuda, ahjus põletada. Tim Ingold on oma animismikäsitluses välja toonud, et selles pole esmatähtis mitte nähtuste agentsus, kuivõrd nende elusus, mis seisneb mh ka nende materiaalse poole pidevas transformeerumises, 
ümbertehtavuses (flows and transformations of materials; Ingold 2013: 214). Objekti (kui elutu) asemel on asi (thing), millel on oma päritolu, tekkelugu, edasikestmine, edasi transformeerumine. Pidevas vormilises muutumises näeb Ingold animismi kui elusolemise olulist tunnust. Seega võiks kasepuude ning neist saadava materjali ja energia kasutamine siin olla sellelaadse animeerituse tõestuseks. Just tänulik ärakasutatavus (ja mitte üksnes harras palumine) annab siin võtme puude tegeliku elususe juurde: neist saab tervistavat mahla ja saunaleili, troitsa-rituaaliks maharaiutuna kasutatakse neid oluliste nähtuste edasikandjatena, nt negatiivsete jõudude külakogukonnast äraviijatena kevadiste pühade lõpul.

Puude rituaalne märgistamine, laasimine, nende loodusliku terviklikkuse rikkumine on tuntud ka muudes olukordades. Läänemeresoome rahvastel on selle ehk tuntuimaks ja enim uuritud ilminguks karjala karsikko (lähemalt Holmberg 1924, Konkka 1986). Sel puhul on kalamees või kütt õnnestunud jahi või püügi korral tähistanud läheduses asunud puu mõne märgiga, raiunud sellelt oksi või lõiganud sellesse daatumi. Sel teel on ta loonud puuga isikliku suhte, sellega otsekui lepingulisse vahekorda astudes. Edasiste õnnestunud püükide korral on ta pidanud seda märgistamispraktikat jätkama ning personaalne vastastikune suhe on niimoodi järjest tihenenud.

Karsikko'tel (aga sarnaselt ka Lõuna-Eesti / setude risti- ja lautsipuudel) on võinud olla ka tõrjemaagiline funktsioon. Neisse lõigatud rist või märk, neilt maha löödud koor või neisse löödud raudese on matuseolukorras tähistanud piiri elavate ja surnute asukoha vahel, kust surnu enam tagasi pöörduda ei tohi. See on puude kui materiaalsete elusolendite kasutamise üks tahk.

On aga täheldatud, et animistlike rahvaste suhe loodusobjektidesse võib skaalal elus-elutu olla diferentseeritud. Danny Naveh ja Nurit Bird-David on näidanud, kuidas Lõuna-India nayaka'd võivad vajadusest tulenevalt pidada puid nii elusateks kui ka elututeks:

(...) puud kui sellised võivad olla hingestatud, mittehingestatud või käsiteldavad objektidena, sõltuvalt sellest, mis tegelikult toimub nende ja nende nayaka suhtluskaaslaste vahel. Kui puud on suhtlusse kaasatud ning muutunud nii tähelepanu ja tundmaõppimise subjektiks, siis võetakse neid kui hingestatuid. Muid puid võib kasulikkuse eesmärgil maha raiuda ehituseks või palgamaksmiseks (nt kui töötatakse metsatööstuses). Kaugemad puud, mis pole käeulatuses ja kättesaadavad, võivad olla käsiteldavad kui mittehingestatud - nt kui etnograafilt küsitakse, kas ja milliseid puid tema kodupaigas kasvab (Naveh ja Bird-David 2013: 29). 
See näide, mis pole maailmas kahtlemata ainulaadne, pakub mõtteainet ka meie vepsa näite puhul. Kuna võisime juba tõdeda, et mets pole ka läänemeresoome rahvakultuuris (ja meie kahe näite puhul) homogeenne sidusala, vaid erinevaid locus'eid sisaldav piirkond, siis pole võimatu, et puude (ja puurühmade) vahel on vajadusel tehtud selget vahet. Vepsa alekultuur on tähendanud teatud metsastunud alade regulaarset maharaiumist ja põletamist, puid on raiutud ehituseks ja kütteks jne. M. A. ja O.F-i jaoks näib konkreetne puu, millega nad suhelda tavatsesid, kategoriseeruvat aga eraldiolevana, "elavamana", igal juhul personaalsemana tuhandete muude metsapuudega võrreldes.

\section{Lõpetuseks: "lekkiv animism" läänemeresoome ontoloogias}

Mida võiks siit järeldada läänemeresoomlastele omase maailmapildi ja selle geneesi kohta üldisemalt?

Tim Ingold on animismi käsitledes pidanud selle oluliseks tunnuseks elususe voolavust (flow), kestmist pidevas transformeerumises. Seega, animistlikus maailmas pole tegemist fikseeritud kontaktsusega, vaid pigem muutliku või otsleva liikumise, muutumisega. Kommenteerides Bruno Latouri arendatud actor-network'i teooriat (vrd ka Latour 1990), tõdeb ta sõna "võrgustik" (network) eksitavust teooria nimetuse ingliskeelses tõlkes. Selle asemel tundub talle kohasem Henri Lefebvre'ilt laenatud meshwork'i mõiste, mis viitab pigem protsessuaalsusele, mitte lineaarsele resultaatsusele, tekstuurile teksti asemel (Ingold 2013: 223-224). Ingold loob paralleeli ämblikuvõrguga, milles pole tegemist niivõrd mingite kommunikatiivsete ühenduspunktidega (võrgustikuga), vaid pigem ämbliku kehalise tegevuse tulemusega, millest putukaid püüdev võrk moodustub ja oma ülesannet täidab. Ämblikuvõrk pole poolabstraktne joonis, vaid ämbliku kehalise elutegevuse saadus, millel on mõte protsessis, mitte ideaalses ettekujutuses. Nii kõneleb Ingold otsekui vastu olemasoleva mistahes ideaalsele plaanipärasusele animistlikus ontoloogias.

Ingoldi animistlikus EWO (environment without objects, Ingold 2013) maailmas rullub sündiv elusolevana järjest lahti, mitte ei ole objektilt agendile sirgjooneliselt tagasiviidav. Sel võrdlusel näib olevat teatud paralleel šamanistliku vs. teadjapõhise läänemeresoomeliku ontoloogia võrdluses. Šamanistliku transi psühhofüsioloogiline "teelolek käänakutagust teadmata" (Bulgakova 2001: 234-235) on oma olemuselt füüsiline (Frog 2013: 61) ja animistlikult protsessuaalne, ka 
siis, kui šamaan on sel moel kohustatud täitma mingit konkreetset ülesannet. Vastupidine näib olukord teadja praktikas. Psühhofüsioloogilise hingerännaku asemel on tema tööriistaks verbaalmaagiline loits (Frog 2013: 61-62), mida võib käsitleda kui oma olemuselt "tagantpoolt ettepoole" kulgevat rekonstruktsiooni, elususe tõmbamist valmisolevale universaalsele liistule.

Raviloitsude kompositsioon läheb olemasoleva probleemi juurest sageli tagasi kahjutekitaja olemuse, tekke, sünni juurde. Näiteks raudesemelt saadud vigastust on teadja ravinud raua mütoloogilist tekkelugu seletava loitsuga, mütoloogilist haigust on loitsus siirdutud murdma või muutma mütoloogilisse universaalruumi, kasutades selleks fikseeritud vormellikku folkloorižanri (historioola) koos vastavate ravipraktikatega. Teadja töö on seega olnud üsna mehaaniline valmismaatriksi kasutamine, milles olemasolevast olukorrast on liigutud tagasi selle tekitanud alge juurde. Loitsude valdamine on teadjale taganud üsna staatilise positsiooni, mis on samas olnud palju võimukam ja domineerivam võrreldes šamaani töö labiilsuse, loomingulisuse ja riskantsusega.

Teadja roll on seega küllaltki "mitteanimistlik". Kuigi ta toimetab endiselt pigem elavate asjade (Ingoldi thing), mitte objektidega asustatud maailmas, on tema tegevuse tendents pigem mehaaniline ning ta agentsus ühesuunaline, sirgjooneline. See pole improvisatsiooniline toimimine seatud eesmärgi saavutamiseks, vaid kindla olemasoleva tee järgimine. Ka läänemeresoome sõna teadma ( $>$ teadja) on etümoloogiliselt pärit noomenist tee (Pyysiäinen 2000: 190).

Nagu eespool juba mainitud, kujunes läänemeresoomelik teadjakeskne kultuuritüüp välja soomeugriliku šamanismi kohtumisel indoeuroopa põlluharimiskultuuridega pronksiajast alates. See tõi kaasa "puhtalt" animistliku kultuuritüübi järkjärgulise segunemise ja kombineerumise dualistliku ja objektistava maaviljelejate maailmavaatega. Kristluse hilisemal järkjärgulisel levikul ei kaotanud kõik animistlikud olendid siiski oma elusust, kuid võisid hakata kujutama endast negatiivseid deemonlikke agente. Pikapeale asenduski šamanistlik variatiivsus teadjaliku agressiivsema, maskuliinsema sirgjoonelisusega.

Animistlikud arusaamad ei kadunud loomulikult kohe ning pole päriselt kadunud siiani. Nad "lekivad" endiselt läänemeresoome rahvaste erinevatest tõekspidamistest, folkloorižanridest ja praktikatest. Võimalik, et ka tänapäeva soome-ugri kunstnike etnofuturistlikes töödes pole toimunud sisulist katkestust, mis neoanimistlikku taasmõtestamist eeldaks. 
Selle artikli kaks puudega suhtlemise juhtu võiksid illustreerida animismi genuiinset kestmist läänemeresoome rahvastel. Selles on esindatud arusaamad looduse elususest ning selle esindajate toimimisest suhtluspartneritena. Samas sisaldab see suhtlemine spontaansust ja emotsionaalsust ilma viideteta nende pöördumiste tseremoniaalseks pateetiliseks poeesiaks etableerumisele. Kõnekas on kosmogoonilisest aspektist ka puude (või teatud puude) roll vahendajatena mälestus- või kalendaarsetes rituaalides, mis on oluline just kollektiivsest, kogukondlikust seisukohast lähtuvalt.

Märkus: Selle artikli valmimist on toetanud Eesti Vabariigi Haridus- ja Teadusministeerium (institutsionaalne uurimisteema IUT 2-43 ning Hõimurahvaste Programm).

\author{
Aadress: \\ Madis Arukask \\ Tartu Ülikool \\ Eesti ja üldkeeleteaduse instituut \\ Jakobi 2, IV korrus \\ 51014 Tartu, Eesti \\ E-post: madis.arukask@ut.ee
}

\title{
Kirjandus
}

Ariste, Paul (1970) "Vadja rahvaluule võlus". Saaremaast Sajaanideni ja kaugemalegi, 89-99. Tallinn: Valgus.

Arukask, Madis (2011) "Communicating across the border: What burial laments can tell us about old beliefs". In Valter Lang, ed. The culture of death, 130-150. (Estonian Journal of Archaeology 15(2).) <http://www.kirj.ee/public/Archaeology/2011/ issue_2/arch-2011-15-2-130-150.pdf $>$. Vaadatud 23.11.2016.

Arukask, Madis (2016) "Vepsa-põhjavene karjusekultuur - rollid, tabud ja seksuaalsus parasvöötme metsavööndi traditsioonilises ühiskonnas". Madis Arukask, toim. Uurimusi vepsa rahvausust, 13-88. (Sator: Artikleid usundi- ja kombeloost 16.) Tartu: Eesti Kirjandusmuuseumi Teaduskirjastus. $<$ http://www.folklore.ee/rl/pubte/ ee/sator/sator16/arukask.pdf $>$. Vaadatud 23.11.2016.

Boyer, Pascal (2002) "Why do gods and spirits matter at all?" Ilkka Pyysiainen and Veikko Anttonen, eds. Current approaches in the cognitive science of religion, 68-92. London: Continuum.

Bulgakova, Tat'jana Diomidovna (2001) Šamanstvo v tradicionnoj nanajskoj kul'ture. Sistemnyj analiz. Väitekirja käsikiri. Sankt-Peterburg. 
Carpelan, Christian (2006) "On archaeological aspects of Uralic, Finno-Ugric and Finnic societies before AD 800". In Juhani Nuorluoto, ed. The slavicization of the Russian North. Mechanisms and chronology, 78-92. (Slavica Helsingiensia 27.) Helsinki. <http://www.helsinki.fi/venaja/nwrussia/eng/Conference/pdf/Carpelan.pdf>. Vaadatud 23.11.2016.

Descola, Philippe (2013) Beyond nature and culture. Chicago: The University of Chicago Press.

Frog (2013) "Shamans, christians, and things in between: From Finnic-Germanic contacts to the conversion of Karelia". Conversions: Looking for ideological change in the early middle ages, 53-97. (Studia Mediaevalia Septentrionalia 23.) Vienna: Fassbaender.

Harvey, Graham (2005) Animism: Respecting the living world. London: Hurst.

Holmberg, Uno (1924) "Suomalaisten karsikoista". Kalevalaseuran vuosikirja 4, 7-82. Helsinki.

Honko, Lauri (1994) "Belief and ritual: The phenomenological context". Lauri Honko, Senni Timonen, and Michael Branch, eds. The Great Bear. A thematic anthology of oral poetry in the Finno-Ugrian languages, 63-77. New York: Oxford University Press, Finnish Literary Society.

Hymes, Dell (1989) [1974] Foundations in sociolinguistics. An ethnographic approach. Pennsylvania: University of Pennsylvania Press.

Ingold, Tim (2013) "Being alive to a world without objects". In Graham Harvey, ed. The handbook of contemporary animism, 213-225. Durham: Acumen.

Judin, Aleksej Valerievič (1999) Russkaja narodnaja duxovnaja kul'tura. Moskva: Vysšaja škola.

Järvinen, Irma-Riitta (2004) Karjalan pyhät kertomukset. Tutkimus livvinkielisen alueen legendaperinteestä ja kansanuskon muutoksista. (Suomalaisen Kirjallisuuden Seuran toimituksia 962.) Helsinki: Suomalaisen Kirjallisuuden Seura.

Kallio, Petri (2015) "The language contact situation in prehistoric Northeastern Europe". In Robert Mailhammer, Theo Vennemann gen. Nierfeld, and Birgit Anette Olsen, eds. The linguistic roots of Europe: Origin and development of European languages, 77-102. (Copenhagen Studies in Indo-European 6.) Copenhagen.

Konkka, Aleksej Petrovič (1986) "Karel'skoe i vostočnofinskoe karsikko v krugu religiozno-magičeskix predstavlenij, svjazannyx s derevom". Naučnye redaktory E. I. Klement'ev, R. F. Nikol'skaja. Etnokul'turnye processy v Karelii, 85-112. Petrozavodsk.

Kon'kova, Ol'ga Igorevna (2009) Vod'. Očerki istorii i kul'tury. Sankt-Peterburg: Muzej antropologii i ètnografii im. Petra Velikogo (Kunstkamera) RAN.

Lang, Valter (2016) "Early Finnic-Baltic contacts as evidenced by archaeological and linguistic data". In Valts Ernštreits and Karl Pajusalu, eds. Studies on Livonian II, 11-38. (Eesti ja soome-ugri keeleteaduse ajakiri. Journal of Estonian and FinnoUgric Linguistics 7 (1).) Tartu: University of Tartu Press. $<$ http://jeful.ut.ee/index. php/JEFUL/article/view/jeful.2016.7.1.01/114>. Vaadatud 23.11.2016. 
Latour, Bruno (1990) "On actor-network theory. A few clarifications plus more than a few complications”. Soziale Welt, 47(4), 369-381. <http://faculty.georgetown.edu/ irvinem/theory/Latour-clarifications.pdf $>$. Vaadatud 23.11.2016.

Napolskikh, Vladimir (1992) "Proto-Uralic world picture: A reconstruction". In Mihály Hoppál and Juha Pentikäinen, eds. Northern religions and shamanism, 3-20. (Ethnologica Uralica 3.) Budapest \& Helsinki: Akadémiai Kiadó, Finnish Literature Society.

Naveh, Danny and Nurit Bird-David (2013) “Animism, conservation and immediacy”. In Graham Harvey, ed. The handbook of contemporary animism, 27-37. Durham: Acumen.

Pal'vadre, Marta Jur'evna (2015) “Otčet o komandirovke k vepsam Leningradskoj oblasti naučnogo sotrudnika Gosudarstvennogo ètnografičeskogo muzeja M. Ju. Pal'vadre. 1934 g.". Ljudmila Valentinovna Korol'kova. Vepsy. Fotografii i rukopisi iz sobranija Rossijskogo ètnografičeskogo muzeja, 197-199. Sankt-Peterburg.

Pyysiäinen, Ilkka (2000) "Variation from a cognitive perspective". In Lauri Honko, ed. Thick corpus, organic variation and textuality in oral tradition, 181-195. (Studia Fennica. Folkloristica 7.) Helsinki: Finnish Literature Society.

Salve, Kristi (1995) "Forest fairies in the Vepsian folk tradition". In Mare Kõiva and Kai Vassiljev, eds. Folk belief today, 413-434. Tartu.

Siikala, Anna-Leena (2002) Mythic images and shamanism: A perspective on Kalevala poetry. (Folklore Fellows' Communications 280.) Helsinki: Academia Scientiarum Fennica.

Vinokurova, Irina Jur'evna (2015) Mifologija vepsov. Ėnciklopedija. Petrozavodsk: Izdatel'stvo PetrGU.

Viveiros de Castro, Eduardo (2012) Cosmological perspectivism in Amazonia and elsewhere. Four lectures given in the department of social anthropology, University of Cambridge, February-March 1998. Manchester: HAU. <http://haubooks.org/ viewbook/masterclass1/cosmological_perspectivism.pdf >. Vaadatud 23.11.2016.

Västrik, Ergo-Hart (2007) Vadjalaste ja isurite usundi kirjeldamine keskajast 20. sajandi esimese pooleni. Alliktekstid, representatsioonid ja tõlgendused. (Dissertationes folkloristicae Universitatis Tartuensis 9.) Tartu: Tartu Ülikooli Kirjastus.

\title{
Arhiiviallikad
}

SKS - Soome Kirjanduse seltsi rahvaluulearhiiv

VE - Paul Ariste "Vadja etnoloogia" kogu Eesti Rahvaluule arhiivis

\begin{abstract}
Madis Arukask: Animistic communication with trees based on two Finnic examples. The article deals with communication with trees in the Votian and Vepsian folk cultures. Two cases are observed where people picking berries or mushrooms in the forest offered food to trees (a spruce and a
\end{abstract}


birch), asking for berries-mushrooms and/or good health in return. The Votian informant also commemorated missing dead people at the same time. The tree can be seen as a communication partner or mediator. In addition, the communication can be analyzed in a broader cosmogonic or ritual context. These cases reflect the animistic worldview and the ontology of the traditional way of life of Finnic peoples, where a shamanistic type of culture was gradually replaced by a tedai/teadja ("the-one-who-knows")-centred one, not later than the Iron Age.

Keywords: animism, communication with trees, Finnic folk belief, the-onewho-knows, Vepsian, Votian 